\title{
Gold Sterile Ore Acid Generation Evaluation, San Juan Argentina
}

\author{
Vanesa Bazan1, Pedro Sarquis ${ }^{2}$, Elena Brandaleze ${ }^{3}$ \\ ${ }^{1}$ CONICET, Instituto de Investigaciones Mineras, Universidad Nacional de San Juan, San Juan, Argentina \\ ${ }^{2}$ Instituto de Investigaciones Mineras, Universidad Nacional de San Juan, San Juan, Argentina \\ ${ }^{3}$ Metallurgical Department and Technology and Materials Develop Center, DEYTEMA, Universidad Tecnológica \\ Nacional, Facultad Regional de San Nicolás, San Nicolás, Argentina \\ Email: bazan@unsj.edu.ar, psarquis@unsj.edu.ar, ebrandaleze@frsn.utn.edu.ar
}

Received 13 August 2014; revised 11 September 2014; accepted 5 October 2014

Copyright (C) 2014 by authors and Scientific Research Publishing Inc.

This work is licensed under the Creative Commons Attribution International License (CC BY).

http://creativecommons.org/licenses/by/4.0/

(c) (i) Open Access

\begin{abstract}
One of the problems that mining represents in relation to the natural watercourses is the possible formation of what we call acid mine drainage, which consists in the emission or formation of water effluents of great acidity, usually rich in sulfate and with variable contents in heavy metals. The drainage mentioned is developed from the metal sulfide and sulfate leaching. Researches about the creation of acid drainage suggest that the formation of these depends directly on various factors: primary mineralogy (neutralizer sulfides and minerals), water presence (whether), oxygen diffusion, grain size, microbiological interaction (bacterium), among others. To study these variables and to relate them with geological factors, static (Acid-Base Accounting) and dynamic (Humidity Cell) tests have been developed, among others. The mentioned tests are applied to a case of a gold deposit situated in the Province of San Juan, which is currently very argued because of its mining activity due to its leaching process. In the sterile mineral obtained from the process, kinetics tests were carried out in humidity cells to simulate the natural oxidation of the primary mineral samples. In the obtained leaching, $\mathrm{pH}$ values closer to neutrality and a limited solution metal presence were detected, indicating the neutralization ability due to the carbonates ores presence.
\end{abstract}

\section{Keywords}

Acid Drainage, Sulfide Ores, Carbonates Ores

\section{Introduction}

One of the problems that mining represents in relation to the natural watercourses is the possible formation of what we call Acid Mining Drainage (AMD), which occurs in a natural way consisting in the emission or formation of water effluents of great acidity, usually rich in sulfate and with variable contents in heavy metals, imply- 
ing an environmental and economic responsibility that mining industry should confront [1]-[6].

Mining activity generally accelerates largely the erosion of the reactive sulfides, providing that it creates conditions that tend to facilitate the air and water movement, give great quantity of material, increase the reactive component superficial surface, and increase the possibility for the microorganisms colonization that catalyzes the oxidation process [7].

In the province of San Juan, the mining activity is taking a major role in the economic environment, however, is highly questionable due to the impacts to the environment. It is for this reason that this paper analyzes the impact that could exercise a sterile mine located north of our province with respect to potential acid generated by it.

The acid drainage is produced by the sulfide hydrolysis and oxidation, and especially the pyrite. Secondary minerals that result from the sulfide oxidation are a complex group of soluble sulfates, hydrated sulfates, hydroxisulfates, metal oxides and hydroxides, clays, carbonates and supergene and diagenetic sulfide. Some of these secondary minerals can have harmful effects on water quality due to the additional acidity release during its formation or the storage acidity release, sulfate or metals (or both sulfate and metals) during its dissolution (e.g. iron and aluminum hydroxisulfates).

The type and distribution of the sulfide ores can vary widely depending on the type of ore storage, mine residuum nature, and the mine phase in which it is found.

For this reason it is necessary to analyze constantly the sulfide oxidation process, especially the pyrite that reacts in the oxidant environment as it is shown in Equation (1) [8]. However, there are basic elements such as carbonates that neutralize the acidity by means of Equation (2).

$$
\begin{aligned}
& \mathrm{FeS}_{2}+15 / 4 \mathrm{O}_{2}+7 / 2 \mathrm{H}_{2} \mathrm{O} \rightarrow+\mathrm{Fe}(\mathrm{OH})_{3}+2 \mathrm{SO}_{4}^{2-}+4 \mathrm{H}^{+} \\
& 4 \mathrm{FeS}_{2}+8 \mathrm{CaCO}_{3}+15 \mathrm{O}_{2}+6 \mathrm{H}_{2} \mathrm{O} \rightarrow 4 \mathrm{Fe}(\mathrm{OH})_{3}+8 \mathrm{SO}_{4}^{2-}+8 \mathrm{Ca}^{2+}+8 \mathrm{CO}
\end{aligned}
$$

From these reactions it can be carried out a drainage generation potential making an Acid-Base Accounting (ABA); this qualitative static test shows just the presence of a generation potential or not [9].

As well as to be able to estimate the amount of acid that could generate the sample by oxidation of sulphide minerals and the power of neutralization of the same ore. As the difference between the Neutralization Potential (NP) and the Acid Potential (AP), the Net Neutralization Potential (NNP) is calculated; in the case it gives a negative value and will show an acid drainage potential ore. On the contrary, positive data of NNP show that the neutralization capacity overcomes the acid generation and therefore the ore is not potentially acid-generating.

Every reported value is expressed in quantity equivalent to calcium carbonate $\left(\mathrm{CaCO}_{3}\right)$ and the criterion applied generally to dismiss every acid drainage risk is that the value of NNP exceeds $20 \mathrm{~kg}$ of $\mathrm{CaCO}_{3}$ equivalent by material per ton [10]. Besides these tests, kinetic tests were carried out implying the drainage water monitoring from the laboratory cells. From the kinetic tests, the primary ore reaction speeds and the secondary ore precipitation controls in the leaching chemical can be tested [11]. These results can be used to assess the development of future geochemical samples [12].

The methodology applied for the determination of drainage in sterile mineral in gold was based on chemical and mineralogical analysis with static and dynamic tests that are described in greater detail in the rest of the paper.

\section{Experimental Procedure}

A sample from a gold deposit in the Province of San Juan was analyzed, in which it is estimated a production of 1600 ton per day, leaving a sterile material from the sulfide ore leaching which contains gold.

The waste is accumulated in the sterile mineral zone and it is for this reason that the possible formation of acid drainage generation is studied.

To study the variables and relate them with the geological factors mineralogical studies have been developed, static (ABA) and dynamic (humidity cells) tests, which are described below.

\subsection{Mineralogical Studies}

The carried out study was concentrated in the size fragments, which means that: 
- a particle size distribution was carried out in the ore that will be study by means of sieves of the Tyler series 3/4", 1/2", 1/4", 6\#, 14\#, 35\#, 50\#, 100\#, 150\#, 200\# and 325\# series. Afterwards chemical analyses were done determining carbonates distribution and total sulfur;

- in -1/2", polished cuts and thin sections were done that then were observed in optic microscope;

- with $-50+100 \#$ and $-100+150 \#$ sizes, briquettes were made which were analyzed later by optic and scanning electron microscope;

- in -325\# an X-ray diffraction study was carried out using a WP1011 Philip Diffractometer.

\subsection{Static Test-Acid-Base Accounting (ABA)}

In this test is necessary to determine:

\section{- Total sulfur}

The sample was taken and a milling was made at $-100 \#$, in which total sulfur was determined by means of gravimetric technique of barium chloride. Then the total acid potential was calculated (AP) multiplying the percentage of total sulfur by 31.25 to convert it in equivalents of calcium carbonates $\left(\mathrm{kg} \mathrm{CaCO}_{3} / \mathrm{t}\right)$. The conversion is based in the calcium carbonate quantity required to neutralized the acid downloaded by the measured sulfur, assuming that initially this is in a pyrite way and it oxidized completely to sulfate and ferric hydroxide $\left[\mathrm{Fe}(\mathrm{OH})_{3}\right]$ [8].

\section{- $\mathbf{p H}$ of the paste}

The paste $\mathrm{pH}$ provides a preliminary suggestion of the acid-net generation associated with a sample, since the $\mathrm{pH}$ is a fundamental control, as much in the primary reaction rates as in the ore solubility. The paste $\mathrm{pH}$ values lower than 6 shows a limited availability of the Neutralization Potential (NP), while higher values suggest that the sample has a certain NP.

The paste $\mathrm{pH}$ was determined measuring the $\mathrm{pH}$ in a mixing grinded sample of 10 grams and distilled water.

\section{- Neutralization potential or acid neutralization capacity}

The potential neutralization was obtained putting $2 \mathrm{~g}$ of the pulverizing sample in a Erlenmeyer of $250 \mathrm{ml}$ it is added HCL and distilled water up to volume, and it was entitled using $\mathrm{NaOH}$. The Neutralization Potential (NP) was calculated in the following way:

$$
\mathrm{NP}=(50 a[x-b / a y]) / c
$$

In which:

NP: Neutralization Potential in tons of $\mathrm{CaCO}_{3}$ equivalent 1000 per tons of material;

$a=$ HCL normality;

$b=\mathrm{NaOH}$ normality;

$c=$ sample weight;

$x=$ HCL $(\mathrm{ml})$ added volume;

$y=\mathrm{NaOH}$ added volume to get the neutralization.

While the Acid Potential (AP), from the ton sample of $\mathrm{CaCO}_{3}$ equivalent 1000 per tons is:

$$
\mathrm{AP}=\text { total sulfur }(\%) * 31.25
$$

The Net Neutralization Potential (NNP) in tones $\mathrm{CaCO}_{3}$ equivalent per 1000 tons of sample is:

$$
\mathrm{NNP}=\mathrm{NP}-\mathrm{AP}
$$

\subsection{Dynamic Test}

Tests were carried out in humidity cells for both samples during 5 weeks, as it is described in the Guides for the Prediction of Metal and DAR Leaching of Columbia Britain.

\section{Results and Discussion}

\subsection{Mineralogical Studies}

In Figure 1 the particle size distribution is observed, together to these results the obtained data in Table 1 are analyzed where it is shown the chemical determinations made in each granulometric kind and the carbonate dis- 


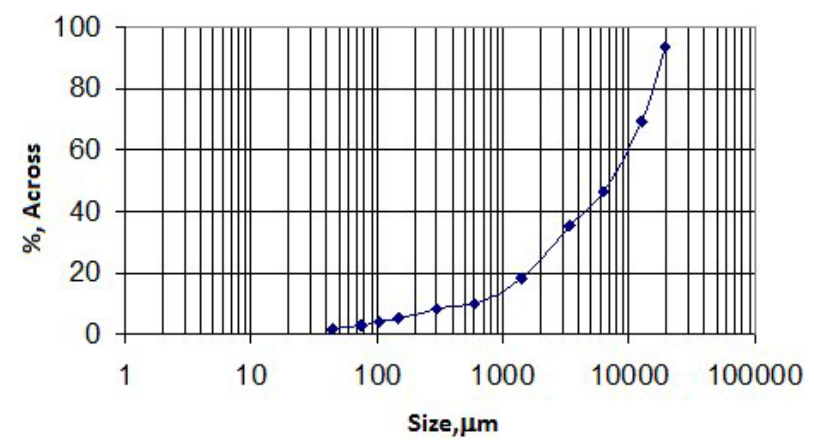

Figure 1. Size distribution of the sample.

Table 1. Chemical analysis and distribution of carbonate and total sulfur in each size class.

\begin{tabular}{|c|c|c|c|c|c|}
\hline \multirow{2}{*}{ Fraction of size } & \multirow[t]{2}{*}{ Weight } & \multicolumn{2}{|c|}{ Content } & \multicolumn{2}{|c|}{ Distribution } \\
\hline & & Carbonate & S total & Carbonate & S total \\
\hline$\mu \mathrm{m}$ & $\%$ & $\%$ & $\%$ & $\%$ & $\%$ \\
\hline$+19,100$ & 6.55 & 32.1 & 0.487 & 7.69 & 7.38 \\
\hline$+12,700$ & 24.28 & 29.3 & 0.325 & 26.02 & 18.23 \\
\hline+6350 & 22.94 & 24.2 & 0.194 & 20.30 & 10.28 \\
\hline+3360 & 11.01 & 23.3 & 0.482 & 9.38 & 12.26 \\
\hline+1410 & 16.87 & 27.3 & 0.513 & 16.84 & 20.00 \\
\hline+590 & 8.16 & 21.5 & 0.594 & 6.42 & 11.20 \\
\hline+297 & 1.73 & 30.3 & 0.684 & 1.92 & 2.74 \\
\hline+149 & 3.02 & 35.3 & 0.724 & 3.90 & 5.06 \\
\hline+104 & 1.26 & 38.2 & 0.861 & 1.76 & 2.50 \\
\hline+74 & 1.10 & 37.6 & 1.107 & 1.51 & 2.80 \\
\hline+44 & 1.08 & 37.5 & 0.893 & 1.49 & 2.24 \\
\hline-44 & 2.01 & 37.7 & 1.144 & 2.77 & 5.31 \\
\hline
\end{tabular}

tribution and total sulfur in each size fragment. The size segments inferior to 100\# present the higher carbonate laws and the size segment lower to 325\# has the higher total sulfur law, making a sample recovery with the obtained data the head sample has a $27.3 \%$ law of carbonates and $0.43 \%$ of total sulfur.

As regards the microscopy observations it can be determined that the sample is constituted mainly by carbonates (calcite) and silicates (quartz, feldspar, mica and possibly andradite), observing also the presence of little sulfide quantities (pyrite, chalcopyrite, chalcocite-covellite and sphalerite) and some sulfates (gypsum and very little quantity of barytes and possibly chalcanthite-brochantite), for example Figures 2-5 is observed.

As regards the kind $-100 \#+150 \#$, the same as in the previous fraction, a briquette was made which then after polished it was studied in optic microscope, making points counting, giving as a result that the sample is constituted by pyrite $0.041 \%$, chalcopyrite signs, iron oxide $1.23 \%$, silicates $42.5 \%$ carbonates (calcite) $36.1 \%$, chalcocite-covellite signs and sulfates $5.33 \%$ mainly gypsum and scarcely calcantita-brocantita.

As regards the X-ray diffraction, Figure 6, it was determined about the size fraction inferior to 325\# (44 $\mu \mathrm{m})$, resulting that the species present with crystalline structure and such abundance that can be detected by the method are: quartz, feldspar, gypsum mica and the calcite which is the predominant ore.

\subsection{Static Test-ABA Test}

In Table 2 the obtained results in ABA test are shown. In this test it is observed that the $\mathrm{pH}$ of the paste obtained is approximately 7 indicating the absence of acidity accumulated. This result reveals the initial conditions of the sample.

The acid potential was calculated under the assumption that all the sulfur is present as pyrite and that all this pyrite reacts oxidizing to sulfate and hydrolyzing the iron to release acid. This means a clear over-estimation of 


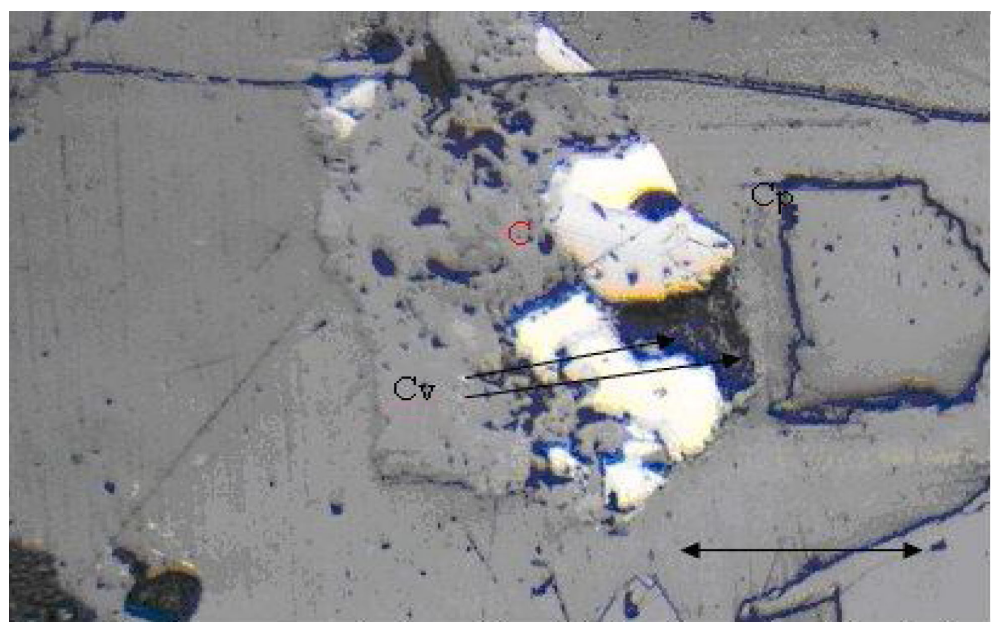

Figure 2. Photomicrograph of a particle of calcite (C) linked to chalcopyrite (CP). Calcosina-Covelina (CV). Objective 16×. Scale $100 \mu \mathrm{m}$.

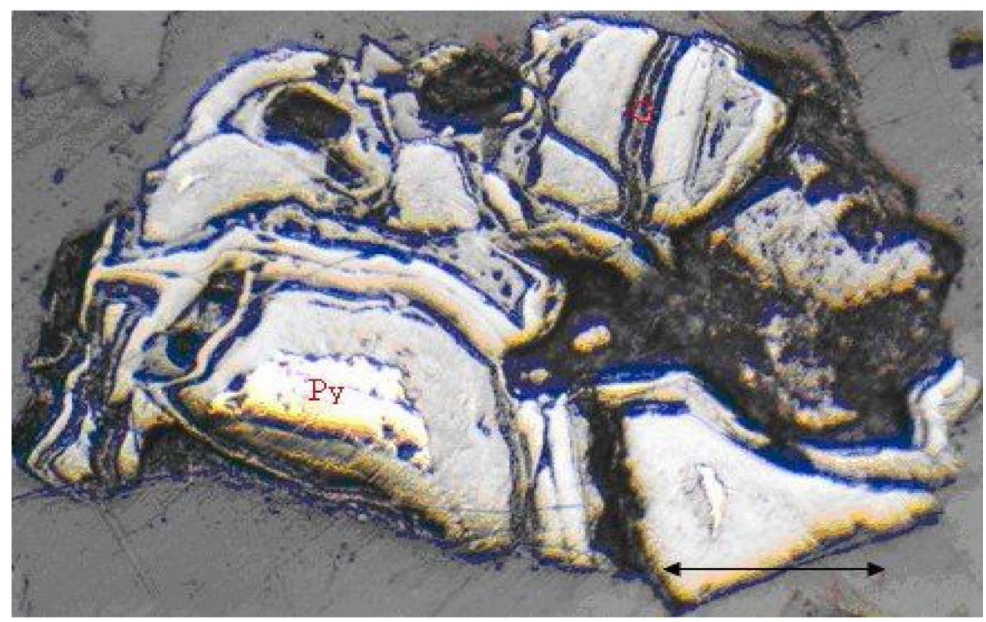

Figure 3. Photomicrograph of particle of goethite $(G)$ with relicts of pyrite (PY). Objective 16×. Scale $100 \mu \mathrm{m}$.

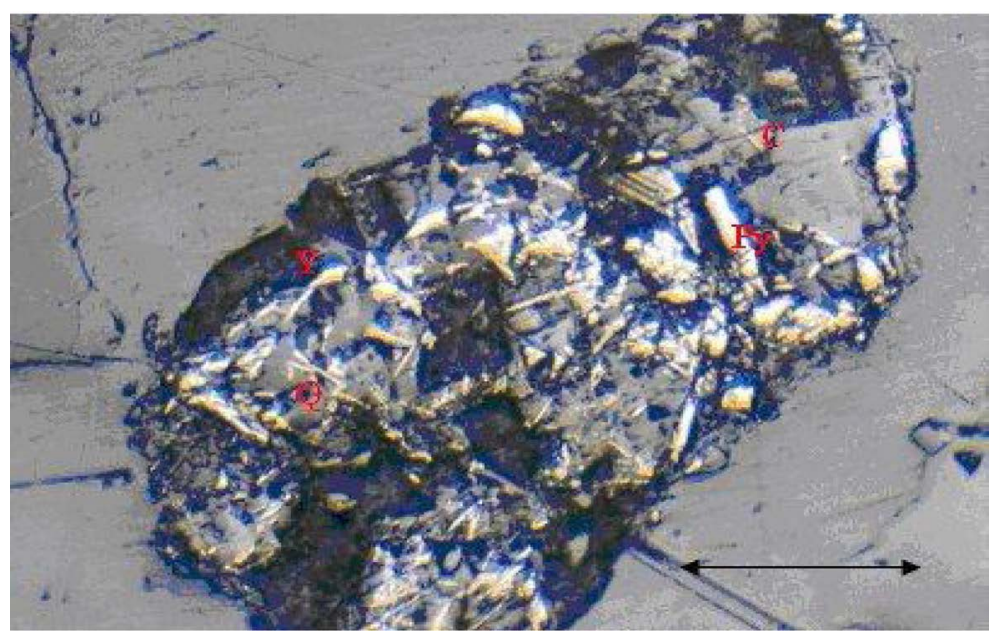

Figure 4. Photomicrograph of complex particle composed of calcite (C). Pyrite (PY) and quartz (Q) and gypsum (Y). Objective 16×. Scale $100 \mu \mathrm{m}$. 


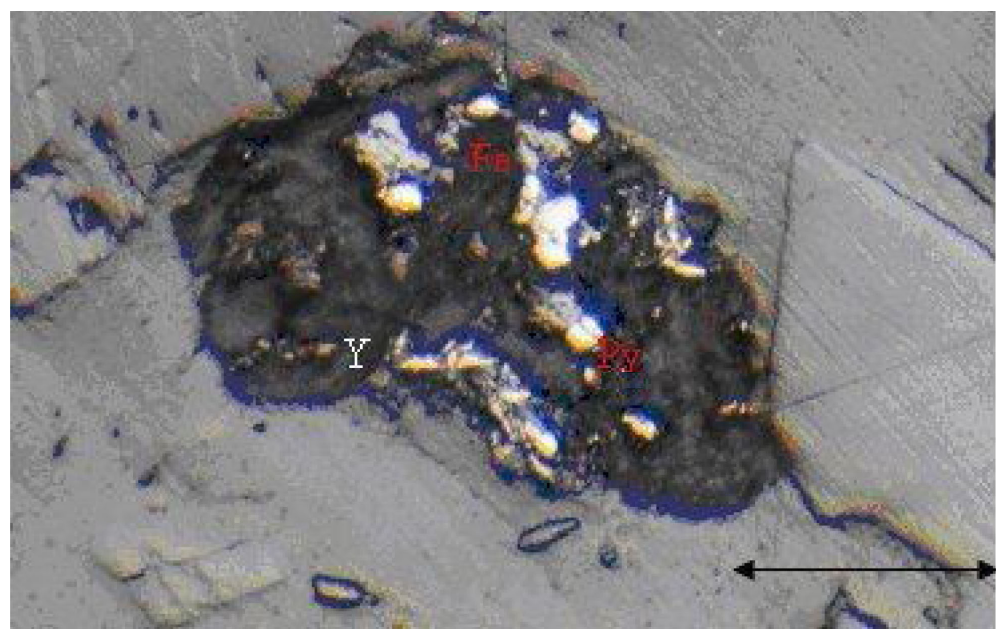

Figure 5. Photomicrograph of gypsum particles (Y) with inclusions in pyrite (PY) and oxides of iron (Fe). Scale $100 \mu \mathrm{m}$.

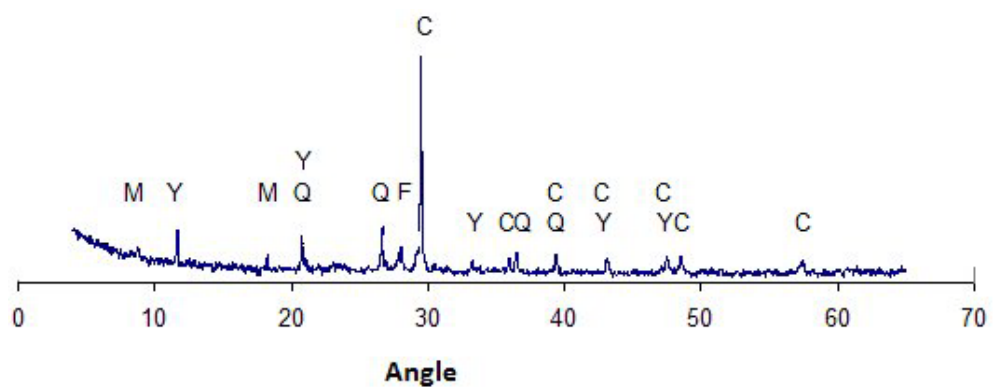

Figure 6. A Rietveld plot of the shows “-325\#”, where C = calcite, $\mathrm{M}=$ mica, $\mathrm{Y}=$ gypsum, $\mathrm{Q}=$ quartz and $\mathrm{F}=$ feldespar.

Table 2. Chemical analysis and distribution of carbonate and total sulfur in each size class.

\begin{tabular}{ccc}
\hline Parameter & Unit & 233.67 \\
\hline The Net Neutralization Potential (NNP) & $\mathrm{kg} \mathrm{CaCO}_{3} / \mathrm{t}$ & 245.57 \\
Neutralization Potential (NP) & $\mathrm{kg} \mathrm{CaCO}_{3} / \mathrm{t}$ & 11.906 \\
Acid Potential (PA) & $\mathrm{kg} \mathrm{CaCO}_{3} / \mathrm{t}$ & 20.62 \\
Relation NP/PA & & 7.15 \\
pH of the Paste & $\mathrm{pH}$ & 0.38 \\
Total Sulfur & $\%$ & \\
\hline
\end{tabular}

the acid generation potential real value.

Even under this scenery that under estimate the acid generation potential real value, the analyzed samples shows net neutralization potentials widely positive, with values between $245.57 \mathrm{~kg}$ of $\mathrm{CaCO}_{3}$ ore ton equivalent. As regards the relation between the neutralization potentials and the acid it is observed that the sample is not acid generating.

It should be mentioned that the total sulfur determination by means of chemical analysis is of $0.38 \%$ while by microscopy determination by means of points counting is of $0.48 \%$ this difference is due to the less accuracy that the latest technique has.

\subsection{Dynamic Test-Wet Cell Test}

Figure 7 shows the $\mathrm{pH}$ variation in relation to the carried out cycles in the duplicated ore humid cell test, with the intention to check the repetition. 
While in Figure 8 the leaching S (\%) variation is analyzed. The soluble sulfate content is higher in the first weeks observing a coming off almost constant and non-appreciable in the last weeks.

In Figure 9, the carbonates ores dissolved Ca concentration is tested, such as calcite $\left(\mathrm{CaCO}_{3}\right)$ present in the rock which neutralize the acidity and maintain the conditions that goes from neutral to alkaline $(\mathrm{pH}>7)$ in the water that flows in the rock. It can be detected also a high magnesium content in solution as a result of the carbonate ore dissolution (Figure 10).

The sulfide ore oxidation release ferrous iron in solution (Figure 11). The ferrous iron chemical oxidation is fast in a $\mathrm{pH}$ higher to 7 and the hydroxide iron precipitate from the solution as a hydroxide. For this reason, the pyrite chemical oxidation speed is relatively low because the ferric iron does not contribute as an oxidizer.

As regards the more questioning metals for the environment as are $\mathrm{As}, \mathrm{Sb}, \mathrm{Hg}$, the sample dissolution is under the detection values, being these lower to the established environmental laws, so they do not represent a risk to this kind of pollution as it can be seen in Table 3, as it is also shown in the chemical compound of the original sample in Table 4.

If we carry out a particular analysis in Figure 12 where the modified Ficklin diagram is shown, they represent the sum of the zinc metal $(\mathrm{Zn})$ concentrations, copper $(\mathrm{Cu})$, lead $(\mathrm{Pb})$, cadmium $(\mathrm{Cd})$, cobalt $(\mathrm{Co})$ and nickel (Ni) and arsenic (As) against the $\mathrm{pH}$. In this case the As is considered because it could be an important element due to its high mobility, however it did not show influence either.

These parameters have been chosen instead of the most common metals such as iron (Fe), aluminum ( $\mathrm{Al}$ ) and magnesium (Mn) due to it has been stated that they are more determinant to geological controls.

In this diagram it was demonstrated that the toxic metals have no mobility in this type of ore and that $\mathrm{pH}$ relation with these state the non-existence of mine acid drainage.

\section{Conclusions}

The studied sample does not present any acid water generation risk, which is stated with the mineralogical studies that resulted in that the ore that provides more $\mathrm{S}$ is gypsum; however it has other provided minor species,
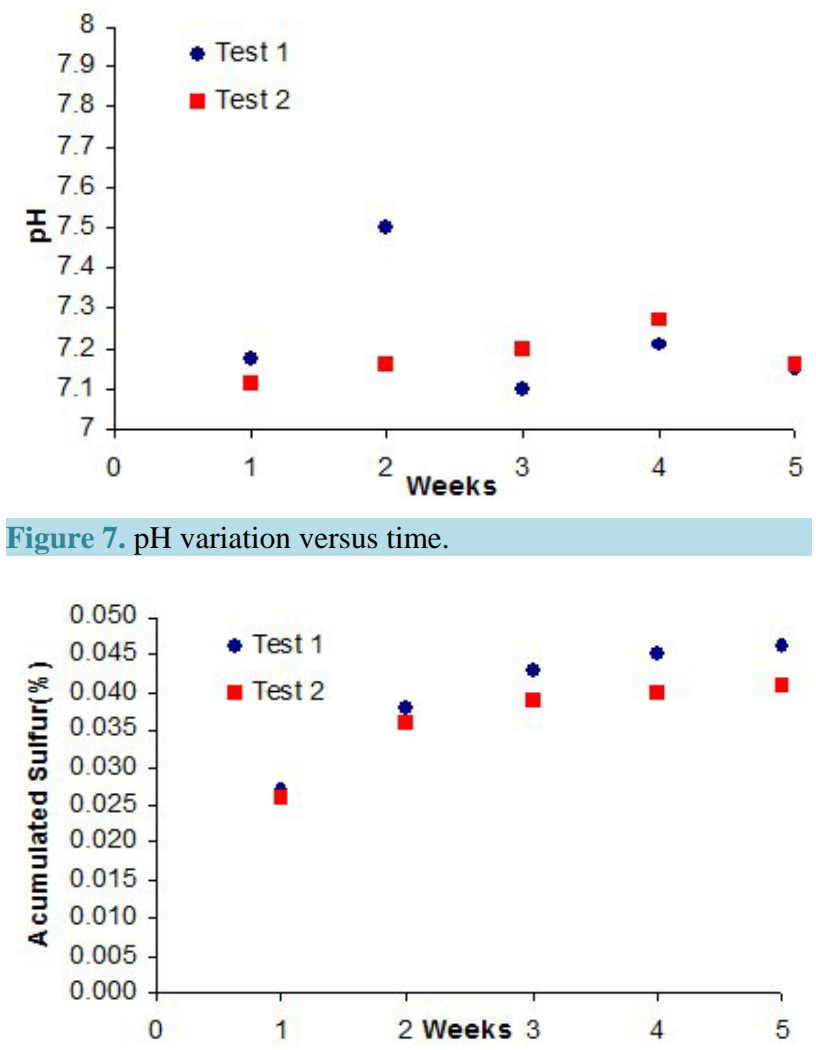

Figure 8. Acumulated sulfur versus time. 


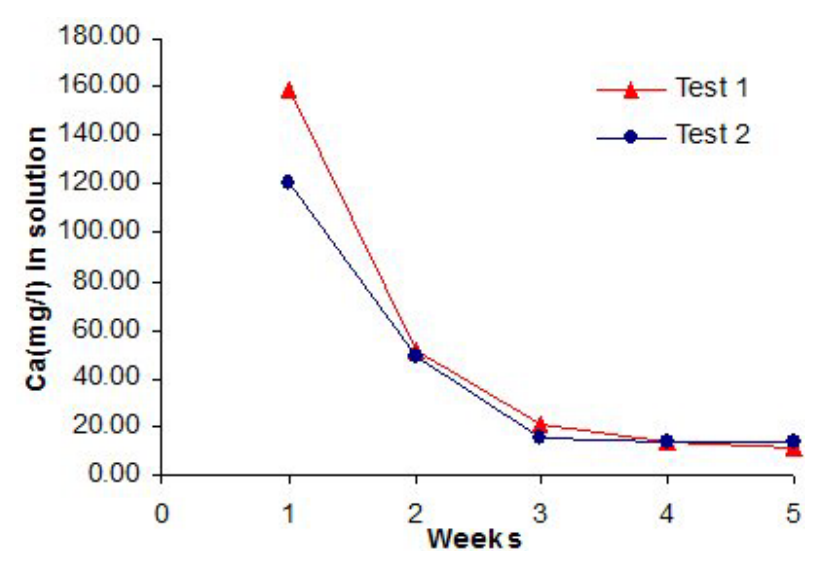

Figure 9. Calcium in solution.

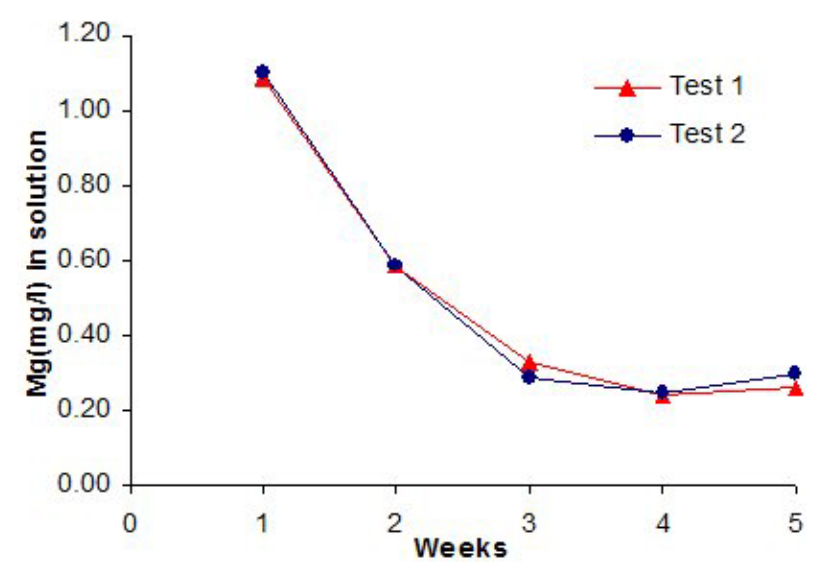

Figure 10. Magnesium in solution.

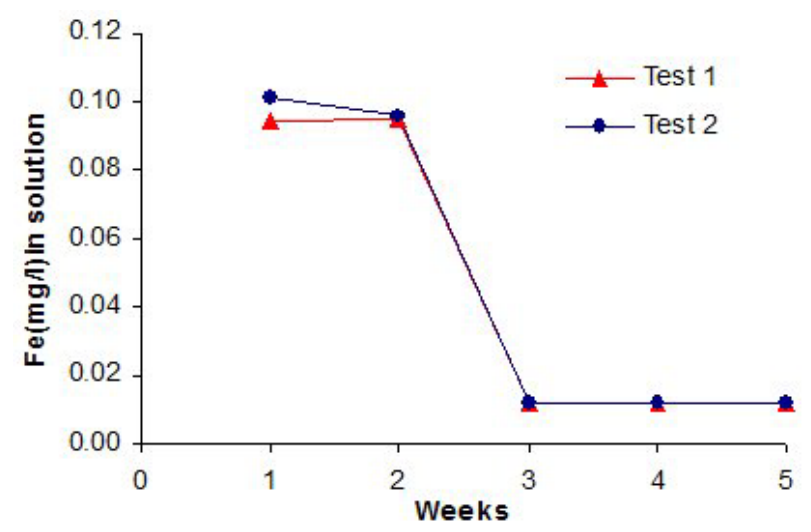

Figure 11. Iron in solution.

of which the most important one to study is pyrite, with $0.62 \%$ content in $-50+100 \#$ size fraction and $0.41 \%$ in $-100+150 \#$ size fraction, according to the electronic microscopy data.

On the other hand, it was determined that it has neutralizing species such as carbonates, provided specially by calcite in $42 \%$ in $-50+100 \#$ size fraction and $0.41 \%$ in $-100+150 \#$ size fraction. As a result it can be concluded that the carbonate existence overcomes largely the species neutralization requirements that could generate acid drainage.

In addition, the mineralogical analysis, the chemical analysis and the standardized tests (ABA) express what have been said as it has positive and high neutralization net potential more than $200 \mathrm{~kg}$ of carbonate per ore 
Table 3. Results of chemical analysis by ICP. Dissolved elements in solutions obtained on Wet Cell.

\begin{tabular}{|c|c|c|c|c|c|c|c|c|c|c|c|c|c|c|c|c|}
\hline Sample & Ag & $\mathrm{Al}$ & As & B & $\mathrm{Ba}$ & $\mathrm{Be}$ & $\mathrm{Ca}$ & $\mathrm{Cd}$ & Co & $\mathrm{Cr}$ & $\mathrm{Cu}$ & $\mathrm{Fe}$ & $\mathrm{Hg}$ & $\mathrm{K}$ & $\mathrm{Li}$ & $\mathrm{Mg}$ \\
\hline Unit & $\mathrm{mg} / \mathrm{L}$ & $\mathrm{mg} / \mathrm{L}$ & $\mathrm{mg} / \mathrm{L}$ & $\mathrm{mg} / \mathrm{L}$ & $\mathrm{mg} / \mathrm{L}$ & $\mathrm{mg} / \mathrm{L}$ & $\mathrm{mg} / \mathrm{L}$ & $\mathrm{mg} / \mathrm{L}$ & $\mathrm{mg} / \mathrm{L}$ & $\mathrm{mg} / \mathrm{L}$ & $\mathrm{mg} / \mathrm{L}$ & $\mathrm{mg} / \mathrm{L}$ & $\mathrm{mg} / \mathrm{L}$ & $\mathrm{mg} / \mathrm{L}$ & $\mathrm{mg} / \mathrm{L}$ & $\mathrm{mg} / \mathrm{L}$ \\
\hline $\mathrm{LC}$ & 0.021 & 0.06 & 0.105 & 0.009 & 0.003 & 0.009 & 0.021 & 0.003 & 0.006 & 0.012 & 0.009 & 0.012 & 0.03 & 0.45 & 0.006 & 0.06 \\
\hline $\begin{array}{l}\text { Test1 } \\
\text { (W1) }\end{array}$ & $<0.021$ & $<0.06$ & $<0.105$ & 0.038 & $<0.003$ & $<0.009$ & 159.1 & $<0.003$ & $<0.006$ & $<0.012$ & $<0.009$ & 0.094 & $<0.03$ & 1.08 & $<0.006$ & 1.09 \\
\hline $\begin{array}{l}\text { Test1 } \\
\text { (W2) }\end{array}$ & $<0.021$ & $<0.06$ & $<0.105$ & $<0.009$ & $<0.003$ & $<0.009$ & 51.19 & $<0.003$ & $<0.006$ & $<0.012$ & $<0.009$ & 0.095 & $<0.03$ & $<0.45$ & $<0.006$ & 0.59 \\
\hline $\begin{array}{l}\text { Test1 } \\
\text { (W3) }\end{array}$ & $<0.021$ & $<0.06$ & $<0.105$ & 0.076 & $<0.003$ & $<0.009$ & 21.05 & $<0.003$ & $<0.006$ & $<0.012$ & $<0.009$ & $<0.012$ & $<0.03$ & $<0.45$ & $<0.006$ & 0.33 \\
\hline $\begin{array}{l}\text { Test1 } \\
\text { (W4) }\end{array}$ & $<0.021$ & $<0.06$ & $<0.105$ & 0.050 & $<0.003$ & $<0.009$ & 13.74 & $<0.003$ & $<0.006$ & $<0.012$ & $<0.009$ & $<0.012$ & $<0.03$ & 0.74 & $<0.006$ & 0.24 \\
\hline $\begin{array}{l}\text { Test1 } \\
\text { (W5) }\end{array}$ & $<0.021$ & $<0.06$ & $<0.105$ & 0.055 & $<0.003$ & $<0.009$ & 11.64 & $<0.003$ & $<0.006$ & $<0.012$ & $<0.009$ & $<0.012$ & $<0.03$ & $<0.45$ & $<0.006$ & 0.26 \\
\hline $\begin{array}{l}\text { Test2 } \\
\text { (W1) }\end{array}$ & $<0.021$ & $<0.06$ & $<0.105$ & 0.029 & $<0.003$ & $<0.009$ & 120 & $<0.003$ & $<0.006$ & $<0.012$ & $<0.009$ & 0.101 & $<0.03$ & 1.11 & $<0.006$ & 1.10 \\
\hline $\begin{array}{l}\text { Test2 } \\
\text { (W2) }\end{array}$ & $<0.021$ & $<0.06$ & $<0.105$ & 0.037 & $<0.003$ & $<0.009$ & 48.7 & $<0.003$ & $<0.006$ & $<0.012$ & $<0.009$ & 0.096 & $<0.03$ & 0.67 & $<0.006$ & 0.59 \\
\hline $\begin{array}{l}\text { Test2 } \\
\text { (W3) }\end{array}$ & $<0.021$ & $<0.06$ & $<0.105$ & 0.020 & $<0.003$ & $<0.009$ & 16.1 & $<0.003$ & $<0.006$ & $<0.012$ & $<0.009$ & $<0.012$ & $<0.03$ & 0.57 & $<0.006$ & 0.29 \\
\hline $\begin{array}{l}\text { Test2 } \\
\text { (W4) }\end{array}$ & $<0.021$ & $<0.06$ & $<0.105$ & 0.017 & $<0.003$ & $<0.009$ & 13.9 & $<0.003$ & $<0.006$ & $<0.012$ & $<0.009$ & $<0.012$ & $<0.03$ & $<0.45$ & $<0.006$ & 0.25 \\
\hline $\begin{array}{l}\text { Test2 } \\
\text { (W5) }\end{array}$ & $<0.021$ & $<0.06$ & $<0.105$ & $<0.009$ & $<0.003$ & $<0.009$ & 13.4 & $<0.003$ & $<0.006$ & $<0.012$ & $<0.009$ & $<0.012$ & $<0.03$ & $<0.45$ & $<0.006$ & 0.30 \\
\hline
\end{tabular}

\begin{tabular}{|c|c|c|c|c|c|c|c|c|c|c|c|c|c|c|c|c|c|}
\hline Mn & Mo & $\mathrm{Na}$ & $\mathrm{Ni}$ & Mg & $\mathrm{P}$ & $\mathrm{Pb}$ & $\mathrm{Sb}$ & Se & $\mathrm{Si}$ & Sn & $\mathrm{Sr}$ & Th & $\mathrm{Ti}$ & $\mathrm{Tl}$ & $\mathrm{U}$ & V & $\mathrm{Zn}$ \\
\hline $\mathrm{mg} / \mathrm{L}$ & & & & & & & $\mathrm{mg} / \mathrm{L}$ & $\mathrm{mg} / \mathrm{L}$ & $\mathrm{ng} / \mathrm{L}$ & & & & & $\mathrm{mg} / \mathrm{L}$ & $\mathrm{mg} / \mathrm{L}$ & $\mathrm{mg} / \mathrm{L}$ & $\mathrm{mg} / \mathrm{L}$ \\
\hline 0.003 & 0.015 & 0.06 & 0.03 & 0.06 & 0.15 & 0.084 & 0.063 & 0.15 & 0.06 & 0.051 & 0 & 0.09 & 0.006 & 0.081 & 0.45 & 0.009 & 0.006 \\
\hline 0.14 & 0.058 & 2.50 & $<0.03$ & 1.09 & $<0.15$ & $<0.084$ & $<0.063$ & $<0.15$ & 3.66 & 0.126 & 0.092 & $<0.09$ & $<0.006$ & 0.127 & $<0.45$ & $<0.009$ & 0.028 \\
\hline 0.05 & 0.042 & 1.06 & $<0.03$ & 0.59 & $<0.15$ & $<0.084$ & $<0.063$ & $<0.15$ & 2.22 & $<0.051$ & 0.056 & $<0.09$ & $<0.006$ & $<0.081$ & $<0.45$ & $<0.009$ & $<0.006$ \\
\hline 0.02 & 0.113 & 2.36 & $<0.03$ & 0.33 & $<0.15$ & & $<0.063$ & $<0.15$ & 1.59 & $<0.051$ & & $<0.09$ & $<0.006$ & & $<0.45$ & & \\
\hline 0.02 & 0.065 & 0.49 & $<0.03$ & 0.24 & $<0.15$ & $<0.084$ & $<0.063$ & $<0.15$ & 1.21 & $<0.051$ & 0.012 & $<0.09$ & $<0.006$ & $<0.081$ & $<0.45$ & $<0.009$ & 0.082 \\
\hline 0.025 & 0.102 & 0.51 & $<0.03$ & 0.26 & $<0.15$ & $<0.084$ & $<0.063$ & $<0.15$ & 1.19 & $<0.051$ & 0.015 & $<0.09$ & $<0.006$ & $<0.081$ & $<0.45$ & $<0.009$ & 0.106 \\
\hline 0.10 & 0.048 & 2.30 & $<0.03$ & 1.10 & $<0.15$ & $<0.084$ & $<0.063$ & $<0.15$ & 3.29 & 0.167 & 0.074 & $<0.09$ & $<0.006$ & $<0.081$ & $<0.45$ & $<0.009$ & 0.026 \\
\hline 0.05 & 0.065 & 0.80 & $<0.03$ & 0.59 & $<0.15$ & $<0.084$ & $<0.063$ & $<0.15$ & 2.63 & 0.099 & 0.035 & $<0.09$ & $<0.006$ & $<0.081$ & $<0.45$ & $<0.009$ & $<0.006$ \\
\hline 0.07 & 0.065 & 0.56 & $<0.03$ & 0.29 & $<0.15$ & $<0.084$ & $<0.063$ & $<0.15$ & 1.21 & $<0.051$ & 0.016 & $<0.09$ & $<0.006$ & $<0.081$ & $<0.45$ & $<0.009$ & 0.137 \\
\hline 0.03 & 0.115 & 0.61 & $<0.03$ & 0.25 & $<0.15$ & $<0.084$ & $<0.063$ & $<0.15$ & 1.12 & $<0.051$ & 0.011 & $<0.09$ & $<0.006$ & $<0.081$ & $<0.45$ & $<0.009$ & 0.140 \\
\hline 0.02 & 0.055 & 1.05 & $<0.03$ & 0.30 & 0.20 & $<0.084$ & $<0.063$ & $<0.15$ & 1.88 & $<0.051$ & 0.005 & $<0.09$ & $<0.006$ & $<0.081$ & $<0.45$ & $<0.009$ & 0.103 \\
\hline
\end{tabular}

ton, indicating a higher basic potential that neutralizes every sample acid ability. What is more it can observe the lower sulfur potential in the sample $(0.38 \%)$ and the recompound by the sample that gives a value of $0.43 \%$; this difference is due to the mistakes of both determinations.

As regards the Humidity Cell Test the mineralogical analysis and the ABA tests conclusions are confirmed, as the $\mathrm{pH}$ variation was measured according to the exposition time. The obtained results give a clear solution neutrality; as regards the soluble sulfate it can be said that there is a majority loosening in the first weeks being this low in relation to the sample total sulfur.

In the chemical analysis by means of ICP (Table 4) it was determined in the original sample Cu $961.7 \mathrm{mg} / \mathrm{kg}$. average, Fe 4.909\% average, As $4.909 \mathrm{mg} / \mathrm{kg}$ average, Ca $>10.00 \%$ average, Na 0.03\% average, K 0.15 average, $\mathrm{Pb} 4 \mathrm{mg} / \mathrm{kg}$ average concentrations among others, nevertheless the dissolute metals in the humid cell test stated a dissolution under the level of detection of $\mathrm{Cu}(0.09 \mathrm{mg} / \mathrm{l})$, As $(0.105 \mathrm{mg} / \mathrm{l})$ and $\mathrm{Pb}(0.084 \mathrm{mg} / \mathrm{l})$ as it is shown in Table 3; referring to the Fe it can be seen in Figure 9 that the mayor dissolution is observed in the first two weeks lowing later; the same behavior is observed for the $\mathrm{Ca}, \mathrm{Na}, \mathrm{K}$ cations which shows that the carbonate and oxide dissolution corroborate again the possible acid drainage neutralization. 
Table 4. Results of chemical analysis by ICP to the sample in duplicat.

\begin{tabular}{|c|c|c|c|c|c|c|c|c|c|c|c|c|c|c|c|c|c|}
\hline Sample & $\mathrm{Ag}$ & $\mathrm{Al}$ & As & $\mathrm{Ba}$ & $\mathrm{Bi}$ & $\mathrm{Ca}$ & $\mathrm{Cd}$ & Co & $\mathrm{Cr}$ & $\mathrm{Cu}$ & $\mathrm{Fe}$ & $\mathrm{Ga}$ & $\mathrm{Hg}$ & $\mathrm{La}$ & $\mathrm{Li}$ & $\mathrm{Mg}$ & $\mathrm{Mn}$ \\
\hline Unit & $\mathrm{mg} / \mathrm{kg}$ & $\%$ & $\mathrm{mg} / \mathrm{kg}$ & $\mathrm{mg} / \mathrm{kg}$ & $\mathrm{mg} / \mathrm{kg}$ & $\%$ & $\mathrm{mg} / \mathrm{kg}$ & $\mathrm{mg} / \mathrm{kg}$ & $\mathrm{mg} / \mathrm{kg}$ & $\mathrm{mg} / \mathrm{kg}$ & $\%$ & $\mathrm{mg} / \mathrm{kg} \mathrm{m}$ & $\mathrm{mg} / \mathrm{kg}$ & $\mathrm{mg} / \mathrm{kg}$ & $\mathrm{mg} / \mathrm{kg}$ & $\%$ & $\mathrm{mg} / \mathrm{kg}$ \\
\hline LC & 0.5 & 0.01 & 5 & 2 & 5 & 0.01 & 1 & 1 & 1 & 1 & 0.01 & 2 & 0.01 & 1 & 2 & 0.1 & 1 \\
\hline Test 1 & $<0.5$ & 0.55 & 102 & 64 & $<5$ & $>10.00$ & 5 & 2 & 40 & 933 & 4.96 & 6 & $<2$ & 7 & 2 & 0.3 & 845 \\
\hline Test 2 & $<0.5$ & 0.53 & 106 & 62 & $<5$ & $>10.00$ & 5 & 2 & 41 & 990 & 4.86 & 5 & $<2$ & 7 & 2 & 0.30 & 830 \\
\hline Mo & $\mathrm{Na}$ & $\mathrm{Nb}$ & & $\mathrm{P}$ & $\mathrm{Pb}$ & S & $\mathrm{Sb}$ & & & & $\mathrm{Sr}$ & Ta & $\mathrm{Te}$ & $\mathrm{Ti}$ & $\mathrm{Tl}$ & V & $\mathrm{Zn}$ \\
\hline $\mathrm{mg} / \mathrm{kg}$ & $\%$ & $\mathrm{mg} / \mathrm{kg}$ & $\mathrm{mg} / \mathrm{kg}$ & $\mathrm{mg} / \mathrm{kg}$ & $\mathrm{mg} / \mathrm{kg}$ & $\%$ & $\mathrm{mg} / \mathrm{kg}$ & $\mathrm{mg} / \mathrm{kg}$ & $\mathrm{mg} / \mathrm{kg}$ & $\mathrm{mg} / \mathrm{kg}$ & $\mathrm{g} \mathrm{mg} / \mathrm{kg}$ & $\mathrm{g} \quad \mathrm{mg} / \mathrm{kg}$ & $\mathrm{kg} \mathrm{mg} / \mathrm{kg}$ & $\%$ & $\mathrm{ng} / \mathrm{kg} \quad \mathrm{n}$ & $\mathrm{mg} / \mathrm{kg}$ & $\mathrm{mg} / \mathrm{kg}$ \\
\hline 1 & 0.01 & 1 & 1 & 10 & 2 & 0.01 & 5 & 5 & 10 & 20 & 1 & 10 & 10 & 0.01 & 5 & 1 & 1 \\
\hline 73 & 0.03 & $<1$ & 4 & 344 & 3 & 0.12 & $<5$ & $<5$ & $<10$ & $<20$ & 77 & $<10$ & $<10$ & 0.06 & $<5$ & 16 & 706 \\
\hline 80 & 0.03 & $<1$ & 5 & 361 & 5 & 0.13 & $<5$ & $<5$ & $<10$ & $<20$ & 76 & $<10$ & $<10$ & 0.06 & $<5$ & 16 & 748 \\
\hline
\end{tabular}

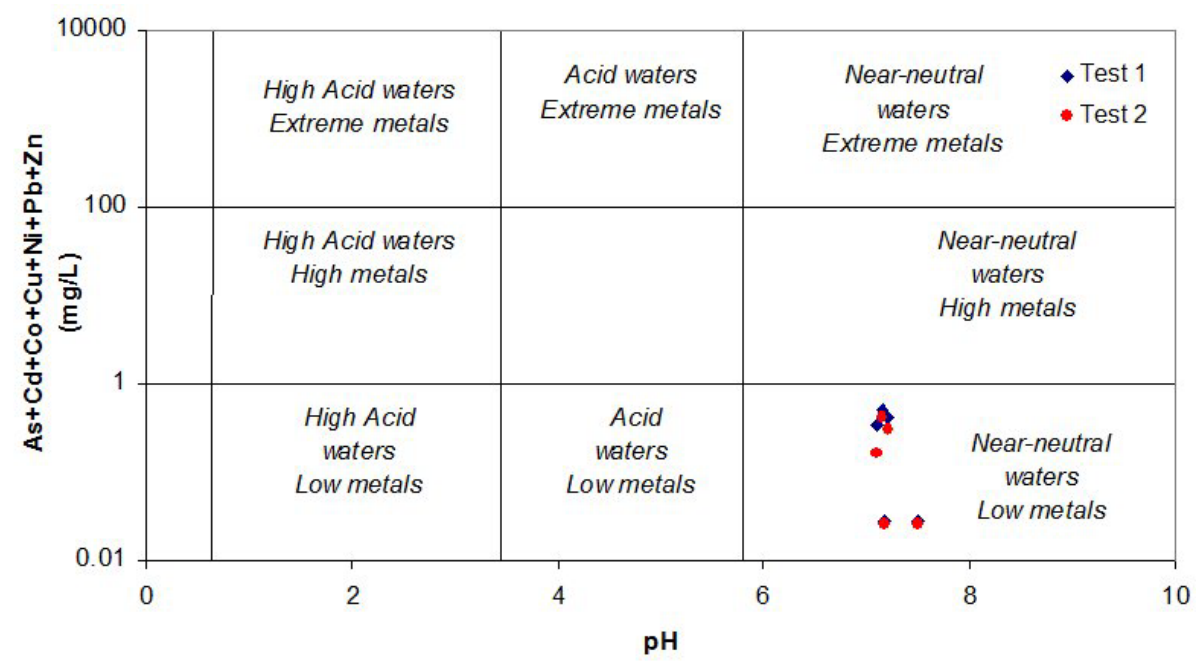

Figure 12. Modified Ficklin diagram.

Finally, from the group of determinations and studies, it is concluded that the analyzed mineral is not an acid drainage generator in this stage of ore processing.

\section{References}

[1] Lapakko, K. (2002) Metal Mine Rock and Waste Characterization Tools: An Overview. Mining, Minerals and Sustainable Development, No. 67.

[2] Mendoza, E., Armiento, M., Ayora, C., Soler, A. and Ramos, E. (2006) Potencial lixiviación de elementos traza en jales de las minas La Asunción y las Torres. en el Distrito Minero de Guanajato. México. Revista Mexicana de Ciencias Geológicas, 23, No. 1.

[3] Johnson, D. and Hallber, K. (2005) Acide Mine Drainage Remediation Options: A Review. Science of the Total Environment, 338, 3-14.

[4] Akcil, A. and Koldas, S. (2006) Acid Mine Drainage (AMD): Causes, Treatment and Case Studies. Journal of Cleaner Production, 14, 1139-1145. http://dx.doi.org/10.1016/j.jclepro.2004.09.006

[5] Lei, L., Song, C., Xie, X., Li, Y. and Wang, F. (2010) Acid Mine Drainage and Heavy Metal Contamination in Groundwater of Metal Sulfide Mine at Arid Territory (BS Mine, Western Australia). Transactions of Nonferrous Metals Society of China, 20, 1488-1493.

[6] Costin, D., Baciu, C., Pop, C. and Varga, I. (2011) Field-Based Kinetic Testing of ARD Potential of the Waste Rock from Roşia Montană ore Deposit (Apuseni Mountains. Romania). In: Rüde, R.T., Freund, A. and Wolkersdorfer, Ch., Eds., Mine Water-Managing the Challenges, IMWA, Aachen, 677-682.

[7] Blowes, D.W., Ptacek, C.J. and Jurjovec, J. (2003) Mill Tailings: Hydrogeology and Geochemistry. In: Jambor, J.L. Blowes, D.W. and Ritchie, A.I.M., Eds., Environmental Aspects of Mine Wastes, Mineralogical Association of Canada. 
[8] Frau, F., Cidu, R. and Dadea, C. (2011) AMD Generation from Dissolution of Secondary Metal Sulphates. In: Rüde, R.T., Freund, A. and Wolkersdorfer, Ch., Eds., Mine Water-Managing the Challenges, IMWA, Aachen, 301-306.

[9] Morales, A. (2003) Determinación y mitigación del potencial de generación acido en botaderos de estériles mina del proyecto Desarrollo Teniente División El Teniente, CODELCO-Chile. Congreso Geológico Chileno, Concepción.

[10] Honig, H., Metzger, C., Pust, C.H. and Schuppe, B. (2011) Dissolution of Various Basic Substances. In: Rüde, R.T., Freund, A. and Wolkersdorfer, Ch., Eds., Mine Water-Managing the Challenges, IMWA, Aachen, 349-352.

[11] Moricz, F., Madai, F. and Walder, I. (2011) Pyrite Oxidation Changes in Sulphidic Mine WASTES from the Itos Sn-Ag Deposit, Bolivia. In: Rüde, R.T., Freund, A. and Wolkersdorfer, Ch., Eds., Mine Water-Managing the Challenges, IMWA, Aachen, 683-688.

[12] Dold, B. (2005) Basic Concepts of Environmental Geochemistry of Sulfide Mine-Waste. In Mineralogía, geoquímica y geomicrobiología para el manejo ambiental de desechos mineros. XXIV Curso Latinoamericano de Metalogenia, Lima, UNESCO-SEG. 
Scientific Research Publishing (SCIRP) is one of the largest Open Access journal publishers. It is currently publishing more than 200 open access, online, peer-reviewed journals covering a wide range of academic disciplines. SCIRP serves the worldwide academic communities and contributes to the progress and application of science with its publication.

Other selected journals from SCIRP are listed as below. Submit your manuscript to us via either submit@scirp.org or Online Submission Portal.
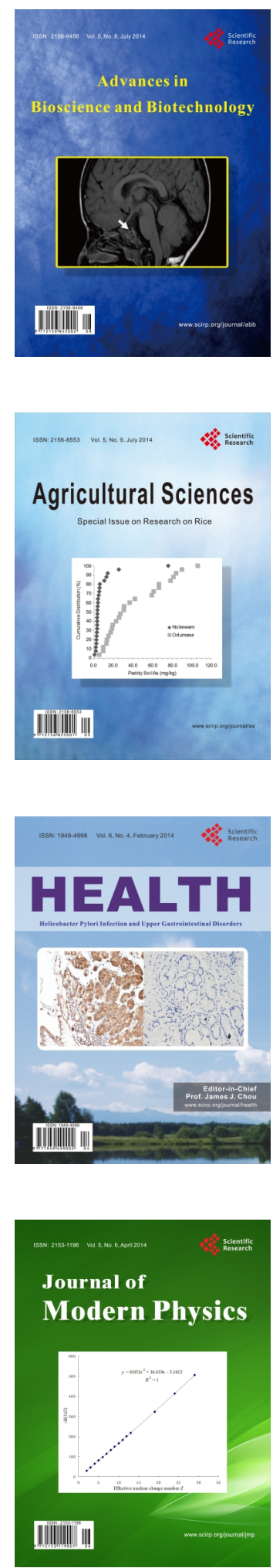
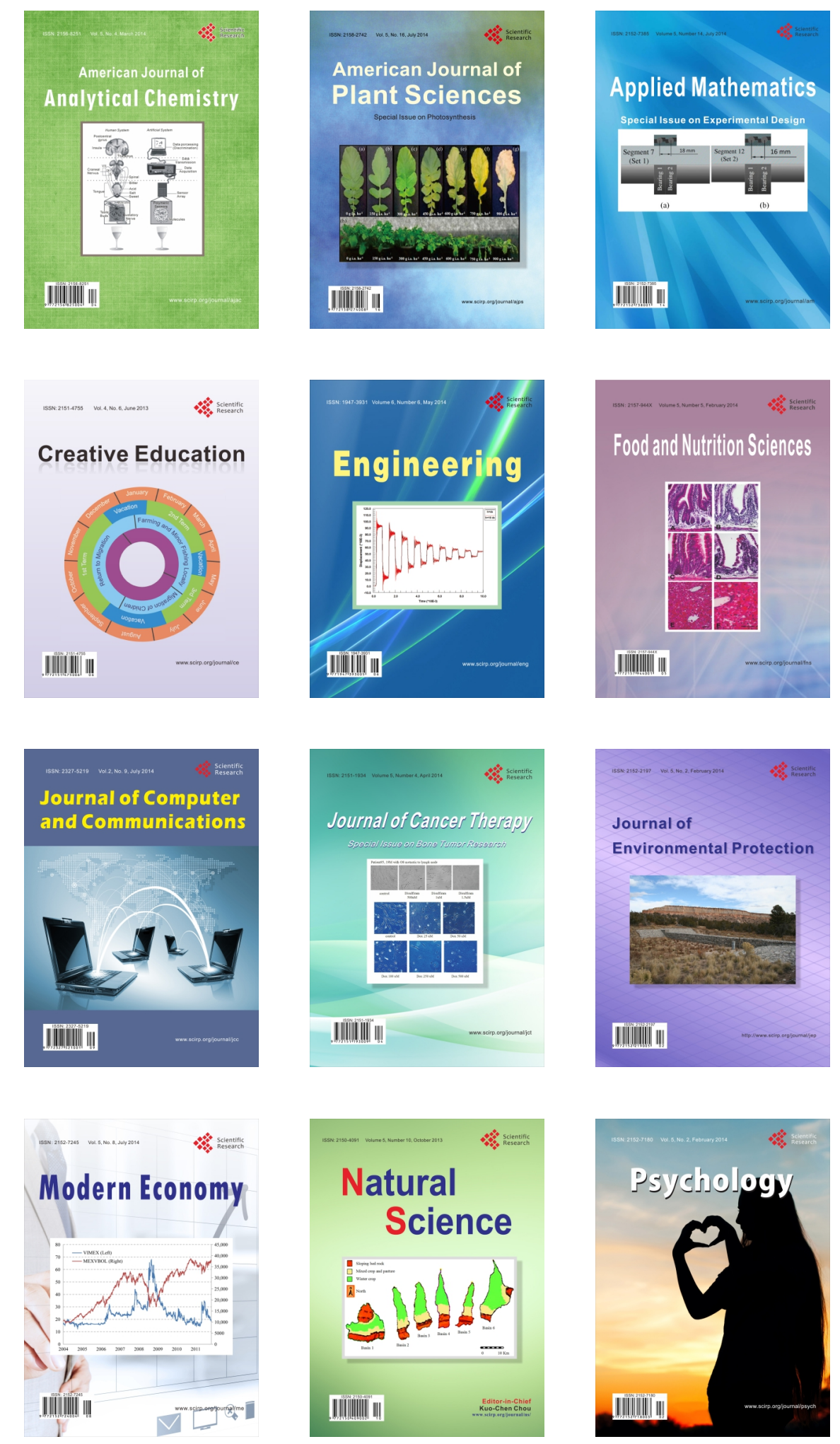